\title{
Factors Hindering High School Library Success as Viewed by Librarians, Teachers and Principals in Israel
}

\author{
Moshe YITZHAKI, Senior Lecturer, \\ Department of Information Studies, Bar-Ilan University, Ramat-Gan, Israel \\ Dania ANZENBERG, Lecturer and Head Librarian, \\ David Yellin Teachers' College, Jerusalem, Israel
}

\begin{abstract}
The paper presents findings of a wide-scale national study of which one objective was to identify main obstacles hindering high school librarians from successfully carrying out their tasks. Similar detailed questionnaires were mailed to librarians, teachers and principals in a cluster sample of 234 schools (one-third of target population), rendering 137 usable questionnaires (58.5\%). The three groups rated quite similarly the obstacles. First and foremost were the scarcities of resources and manpower. Third was inadequate professional training, which was found to include: inadequate training in information technology and in librarianship, scarce skills in management, communication and public relations, as well as lack of training in instruction and lack of familiarity with curriculum and its development. Fourth was the principal's and teaching staff's lack of awareness and recognition of library importance, also acknowledged by principals and teachers. Additional obstacles mentioned were poor physical conditions, discipline problems and the character of the librarian and staff. Recommendations include: promoting understanding of school library and librarian roles by writing Israeli Information Power and by offering courses to principals and teachers on school library's roles, adding personnel positions in school libraries and emphasizing technological topics in library education programs.
\end{abstract}

\section{Introduction}

An abundant and active library is an important feature of any school and can significantly contribute to the attainment of contemporary educational objectives. Many studies indicate a positive link between academic achievements and excellence and the existence of a school library. Student achievements improved when library activity was appropriately incorporated into the curriculum (Gehlken, 1994; Sadowski \& Meyer, 1994; Stripling, 1997; Kennedy-Manzo, 2000).

Although is it widely agreed that the library is an ideal tool for promoting academic excellence, in practice this potential is not always fully realized. Professional literature suggests several major reasons for this: outdated notions of principals and teachers frequently based on their own childhood experiences, absence of a clear-cut definition of the library's role in school compounded by the need for constant change and updating and finally, lack of trust and communication between the library and other school staff members.

The few studies conducted in Israel combined with firsthand knowledge reveal a deplorable state of affairs in many school libraries. Any attempt to remedy the 
situation necessitates clarification of school librarians' perception of their own role and that of the library, their goals and to what extent they are attained and the factors assisting or hindering them in performing their role.

\section{Research Objectives}

The comprehensive study, part of which is described in this paper, had three objectives: to examine the role perceptions of high-school librarians in Israel as viewed by principals, teachers and librarians, to define the characteristics of librarians considered successful at their job and to identify the major obstacles preventing highschool librarians from properly performing their job. Due to the broad scope of findings the current paper was confined only to the third objective, i.e. the difficulties hindering librarians in fulfilling their role in what they consider an optimal manner.

\section{Literature Review}

Four elements can facilitate or alternately, hinder a librarian's work: the librarian himself, the school principal, the teaching staff and library characteristics.

The librarian:

Numerous studies and articles urge librarians to be aware of their potential contribution to the school system and their leading position. Professional competence and technical ability are important to a librarian's success (Christensen, 1991; Shantz, 1994) but are not enough. Roach (1989) claims that the extent of librarian involvement in the overall school program and good effective communication with the principal and teachers bear very significantly on the teaching staff's attitude towards the librarian and on the successful performance of his tasks. Ervin (1989) concludes from her study that the second most important obstacle is the school staff's lack of understanding, awareness or regard for the librarian's qualifications and potential. Librarians must first cultivate a favorable self-image, project it outwardly and convince others of the benefit to be gained from the library and librarian. Johnson (1993), too, asserts that to attain professional recognition, librarians must display qualities of leadership, demonstrate expertise in the media and instruction fields and promote library programs through communication and good interpersonal relations.

Ken Haycock, a prominent researcher of school libraries, wrote the following in an editorial: "We [school librarians] must tell our story, to ensure that decisions are made based on facts rather than on stereotypes or assumptions. We must clarify our role to our employers so that we are counted and supported in our work" (Haycock, 1999: 7). A similar point was made several years earlier in Britain by Heeks and Kinnell: "We must make things happen.... Librarians still have low self-esteem and are reluctant to leave [the library] and spread their gospel" (Heeks \& Kinnell, 1994).

Vansickle (2000) studied 150 students training to become school librarians in five universities in the southern US and found that respondents regarded themselves more as supporters than as leaders. Analyzing the librarian's image, Gary Hartzell concludes that all too often the school staff fails to associate the librarian even with aspects of information searching and does not think to inform him about the school curriculum. The isolated librarian is not perceived as playing any part, direct or indirect, in student progress. A teacher's success is quite obviously measurable by student 
achievement, but the librarian's contribution to teacher success is unknown. A librarian's erudition is not enough to gain attention, empowerment or influence, hence the conclusion that his/her knack for interpersonal and public relations is a significant determinant of success or failure (Hartzell, 1997, 2002). The prominent theme in the responses of 500 principals in Arizona was the hope for better interpersonal communication with the school librarian (Edwards, 1989).

The importance of good public relations is also evident in Latrobe's study (1992) which examined change and improvement in 108 school libraries in Oklahoma, following publication of the first edition of the Information Power manual (1988). Using a tool developed on the basis of guidelines in this manual, librarians were asked to evaluate their library plans from April 1988 to April 1991. They described their initial objectives and elements that facilitated or thwarted their attempts to achieve these goals in those three years. Comparison of the collected data reveals slow but steady progress in attaining library goals. Among the factors mentioned as obstacles or hindrances were relations between the librarian, principal and school staff and the librarian's rigid schedule. An important finding was the list of elements that contributed to the librarian and library's success: $38 \%$ of the most beneficial elements were related to favorable public relations. A librarian's personality traits also figured considerably: devotion, enthusiasm, willingness to work hard and knowledge of informal education.

The importance of a librarian's personality traits is further reinforced by Paul Christensen (1991) who conducted a qualitative study of in-depth interviews with principals, teachers and librarians in Washington and based on these constructed a model of exemplary high-school libraries and librarians. An outstanding librarian is characterized by leadership, initiative and responsibility and dispels the popular stereotype of the librarian as a dull "bookish" type. Rather s/he presents an imaginative, creative and intelligent figure. A later study by Johnson (1993) also underscores the importance of the librarian's traits, such as initiative and enthusiasm. In McCracken's study (2000), too, many librarians indicated personality traits (e.g. decisiveness and creativity) and ambition as factors contributing to their performing their job.

\section{The Principal:}

The most important factor in the school library's function is the principal, whose staunch support, or lack thereof, often determines the library's fate (Burnell, 1978). This assertion, in various phrasings, appears frequently in professional literature that stresses the principal's pivotal role in the library's success (Haycock, 1985; Master \& Master, 1986; Turner, 1985; Wilson \& McNeil, 1998; Hopkins \& Zweizig, 1999).

In two major studies of experienced and novice librarians, Diana Oberg (1996) found that respondents believed that a principal's support can be manifested in diverse ways that express how he "views" the librarian, renders him visible and supports his work. Assessing the extent of librarians' commitment to Information Power guidelines, McCarthy (1997) found that one of the most significant factors preventing the application of these guidelines in the librarians' opinion was lack of principal support. Principals supposedly do not comprehend the library's vital role in education and consider it marginal (Glick, 2001). This theme reemerged recently in a 2002 editorial in the School Library Journal which lists among the five major challenges of the year the need to gain recognition from school principals (Lifer, 2002).

\section{Teachers:}


Many studies suggest that even in the case of plentiful resources, a skilled library staff and an understanding principal, without cooperation from teachers a library will remain unused (Haycock, 1985; Streatfield \& Markless, 1994; Hayden, 2000; Kolencik, 2001). Griffin \& Lamb (1987) stress the importance of reinforcing cooperation between the library and teachers and suggest several practical methods, such as holding a joint workshop for fostering a positive approach and respectful attitudes. Turner (1996) points out the type of help teachers would like to get from the librarian and the library and what steps will they take to get it.

Irit Getz (1996) compared the attitudes of veteran teachers and those of college students with regard to cooperation with school librarians in the education process. She discovered inconsistency between theoretical attitudes, which were very positive, and the extent of actual teacher-librarian cooperation, which was low. Getz found significant, though not strong, links between teacher attitudes and the following variables: level of overall cooperation among school teaching staff, extent of teachers' familiarity with the librarian's present-day roles and professional training and teachers' experiences with the library and librarian as high-school students.

Librarians in McCracken's study (2000) noted teacher support as a strengthening factor and the importance of teachers' willingness to use new aids. Conversely, lack of interest and support on the part of teachers was mentioned as an obstacle to fulfilling their roles. They claimed that many teachers view the librarian as a school "babysitter" and the library as a mere work room and do not have time to collaborate with the librarian.

\section{Library Characteristics:}

This expression denotes factors such as budget, equipment, personnel and physical space. Burnell (1978) concluded that satisfaction with the library and library success are related to the availability of greater resources to those libraries. School librarians in Oklahoma interviewed by Latrobe (1992) noted budget as the second most important factor and claimed that the majority of factors hindering the progress of library work were related to time or money. A study by McIntosh (1994) on the causes of job stress among school librarians in Kentucky also suggests that primary causes are lack of adequate time to perform all tasks and the need to balance the various role demands and technological innovations. Additional causes mentioned there were shortage of personnel and funds. These findings are corroborated by other studies (Callison \& Morris, 1986; NcCarthy, 1997; Kolencik, 2001).

In summation, the literature review underscores the importance of the librarian's self-image and his ambition to lead, change and improve. However, it is difficult to advance and develop the library without a sufficient budget and without the principal's genuine support and backing, which are key to effective cooperation with the teaching staff,

\section{Methods}

\section{Target Population and Sample:}

The study's target population consisted of librarians, principals and teachers in all kinds of high schools in the Jewish sector in Israel, excluding ultra-orthodox, extern or special education schools. The sample cluster of schools was systematically 
selected with a random starting point from the official General Directory of Secondary Education Institutions in the 1998-1999 School Year. The sample's proportion of public to public-religious schools and urban communities to towns and rural settlements reflected actual ratios in the whole population. The selected sample contained 234 schools, which constitute a third of the schools in the directory. Usable questionnaires were obtained from 137 schools, i.e. a response rate of 58.5\%. 24 schools were visited by the head researcher and personal interviews were conducted based on questionnaires identical to those mailed to the other schools in the sample.

The research tools were three similar, but not identical, questionnaires composed for each of the three groups comprising the studied population: librarians, principals and teachers. The first part of each questionnaire contained general and demographic questions regarding the school, library and librarian. The second part consisted of 30 statements formulated using professional literature and supposedly expressing the four contemporary librarian's roles: information expert, teacher, consultant on education and instructional matters and director of library programs. These roles were borrowed from the two editions (1988 and 1998) of Information Power, the American manual of school library management. On a five point Likert scale, respondents were asked to rate each statement twice: once denoting their ideal perception of the role described and again indicating to what extent it was actually performed. The third part of the questionnaire contained broader questions, mostly open-ended, intended to elicit a deeper understanding of the respondent's personal outlook. Data was analyzed using the SAS statistical package.

\section{Findings and Discussion}

The responses obtained reveal that the overall allotment of library manpower (i.e. personnel) per school averaged 2.4 positions, which were not always occupied by professional personnel. The annual budget per library ranged from zero (about $6.5 \%$ of the libraries) to over US $\$ 2300$ in the upper $50 \%$ of the schools, and from $\$ 500$ to $\$ 2300$ annually in $28 \%$ of the schools. The librarians' professional training was as follows: $11.6 \%$ had completed phase I or II of the Israeli Librarians Association, 45.2\% possessed a "Licensed Librarian" diploma, only $22.6 \%$ had full academic librarian training and $20.6 \%$ lacked any librarian training. The average seniority of the responding librarians was 14.1 years.

As mentioned, a central objective of this study was to identify the main obstacles hindering high-school librarians in performing their job. Librarians were asked what these obstacles are, in their opinion and were told to indicate any factor they considered relevant from a given list in the questionnaire and add to it freely. The closed and open-ended answers were classified into 14 categories constituting main obstacles. Findings and rankings are displayed in Table 1, of which several conclusions can be drawn: 
Table 1. Major Obstacles Hindering the Librarian in Performing Her/His Job (in descending order of frequency according to librarians' response)

\begin{tabular}{|l|c|c|c|c|c|c|}
\hline \multicolumn{1}{|c|}{ According to } & \multicolumn{2}{l|}{ Librarians } & \multicolumn{2}{l|}{ Teachers } & Principals \\
\hline \multicolumn{1}{|c|}{ Obstacles } & $\%$ & Rank & $\%$ & Rank & $\%$ & Rank \\
\hline Lack of resources & 61.3 & $\mathbf{1}$ & 70.1 & $\mathbf{1}$ & 56.2 & $\mathbf{1}$ \\
\hline $\begin{array}{l}\text { Lack of time and/or } \\
\text { personnel }\end{array}$ & 53.3 & $\mathbf{2}$ & 45.3 & $\mathbf{2}$ & 45.3 & $\mathbf{2}$ \\
\hline $\begin{array}{l}\text { Inadequate } \\
\text { professional training }\end{array}$ & 23.4 & $\mathbf{3}$ & 17.5 & $\mathbf{4}$ & 27.0 & $\mathbf{3}$ \\
\hline $\begin{array}{l}\text { Principal and } \\
\text { teachers disregard } \\
\text { library's importance }\end{array}$ & 21.9 & $\mathbf{4}$ & 29.9 & $\mathbf{3}$ & 19.7 & $\mathbf{4}$ \\
\hline Student misbehavior & 21.2 & $\mathbf{5}$ & 11.7 & $\mathbf{5 . 5}$ & 10.2 & $\mathbf{7}$ \\
\hline Physical conditions & 10.9 & $\mathbf{6}$ & 9.5 & $\mathbf{7}$ & 13.1 & $\mathbf{6}$ \\
\hline $\begin{array}{l}\text { Library staff's work } \\
\text { and personality }\end{array}$ & 7.3 & $\mathbf{7}$ & 11.7 & 5.5 & 16.0 & $\mathbf{5}$ \\
\hline $\begin{array}{l}\text { Computer related } \\
\text { problems }\end{array}$ & 5.8 & $\mathbf{8}$ & 2.9 & $\mathbf{8 . 5}$ & 0.7 & $\mathbf{1 3}$ \\
\hline $\begin{array}{l}\text { No obstacles; school } \\
\text { is supportive }\end{array}$ & 4.4 & $\mathbf{9}$ & 2.9 & $\mathbf{8 . 5}$ & 6.6 & $\mathbf{8}$ \\
\hline $\begin{array}{l}\text { Librarian's salary } \\
\text { and work hours }\end{array}$ & 3.6 & $\mathbf{1 0}$ & 0 & $\mathbf{1 3}$ & 2.2 & $\mathbf{9}$ \\
\hline $\begin{array}{l}\text { Serving as regional } \\
\text { library causes } \\
\text { conflict of interests }\end{array}$ & 2.9 & $\mathbf{1 1}$ & 0.7 & $\mathbf{1 0 . 5}$ & 0.7 & $\mathbf{1 3}$ \\
\hline Impatience of users & 1.5 & $\mathbf{1 2}$ & 0 & $\mathbf{1 3}$ & 1.5 & $\mathbf{1 0 . 5}$ \\
\hline $\begin{array}{l}\text { Lack of continuing } \\
\text { education }\end{array}$ & 1.5 & $\mathbf{1 3}$ & 0 & $\mathbf{1 3}$ & 0.7 & $\mathbf{1 3}$ \\
\hline $\begin{array}{l}\text { Makeup of school } \\
\text { population }\end{array}$ & 0.7 & $\mathbf{1 4}$ & 0.7 & $\mathbf{1 0 . 5}$ & 1.5 & $\mathbf{1 0 . 5}$ \\
\hline
\end{tabular}

Note: Percentages total more than $100 \%$ because respondents were allowed to mark more than one option.

The obstacles were rated quite similarly by the three groups of respondents, particularly for the first half of the list. The fact that the three groups reached similar conclusions reinforces the reliability of the responses, especially since this was the last item in the questionnaire, in which respondents tend to be less careful.

Predictably, the most significant obstacles, according to respondents, were the shortage of resources and personnel, a problem mentioned by $45 \%$ to $70 \%$ of them. Phrases like "We're always short of resources", "We could use more funding", "I could do much more with added manpower" recurred both in the interviews and in the openended questions. One librarian remarked during her interview: "Your questions imply that in the course of a workday I should initiate work plans with teachers, be updated both on current research and technological innovations, conduct public relations, etc. When?! It's impossible unless I work till midnight every day". Asked whether the librarian should be familiar with the curriculum, a principal replied: "I think that's 
asking too much". After relating some of the fascinating things she had heard in inservice training, the librarian sighed: "It's discouraging. I can't do all that"...

This is consistent with a finding emerging from the analysis of statements in the second part of the questionnaire. When the statements were arranged in descending order of differences between the mean "ideal" and "actual" scores, the library budget item ranked high, third on the list, with a mean "ideal" score of 4.89 (on a 1 to 5 scale) and mean "actual" only 3.47, a difference of almost one and a half units. The questionnaire's demographic data indicates a mean of 2.4 personnel positions per library and that $46 \%$ of the libraries have an annual budget of less than US $\$ 2300$, with $28 \%$ not reaching even 1150. Apparently, all three groups of respondents (librarians, teachers and principals) agree that the allocation of resources and personnel in school libraries is inadequate.

This finding corroborates many former studies mentioned above which found that inadequate resources are one of the major obstacles hindering the success of the school library. Shortage of personnel and funds was pointed out by Burnell (1978), Callison \& Morris (1986), Latrobe (1992), McIntosh (1994), NcCarthy (1997), and Kolencik (2001), among many others, as a most important factor hindering the progress of library work. Lack of funding means inability to acquire new books, information sources, computers, auxiliary equipment, etc. Shortage of personnel means that one librarian serves about one thousand students or is obliged to work in two different places (McCracken, 2000). Another adverse and clearly impeding consequence is an inflexible schedule, also indicated in other studies (Bishop, 1989; Turner \& Zsiray, 1990; McCarty, 1997) which invariably conclude that flexibility of a librarian's hours, suited to class schedules and coordinated with the school staff, greatly contributes to success.

Ranked fourth (or third by teachers) is the disregard displayed by principals and teachers concerning the library and the librarian, reflecting a lack of awareness and recognition of library importance. This attitude is illustrated by responses such as: "S/he is barely visible", "The library is often forgotten" (a principal), "Teachers are indifferent and don't have the time and/or interest" (a principal), "Decisions are made by the principal, I don't have a say in anything" (a librarian) and "I'm forced to accept entire classes and hold lessons" and "I'm expected to be stock keeper for the schoolbook loan project". Such quotes reveal that both teachers and principals, and not merely librarians, concede the lack of awareness and regard.

As already mentioned above, Ervin (1989) too concluded that the second most important obstacle was the school staff's lack of understanding, awareness or regard for the librarian's qualifications and potential. The most important factor in the school library's function is the principal, who plays a pivotal role in the library's success. His staunch support, or lack thereof, often determines the library's fate, as is frequently stressed by many writers cited above (Burnell, 1978; Haycock, 1985; Master \& Master, 1986; Turner, 1985; McCarthy, 1997; Wilson \& McNeil, 1998; Hopkins \& Zweizig, 1999). Unfortunately, as pointed out by Glick (2001) and as indicated also in our study, many principals supposedly do not comprehend the library's vital role in education and consider it marginal. A major challenge for the school librarian is to gain professional recognition from the principal (Lifer, 2002), by cultivating a favorable selfimage, projecting it outwardly and displaying qualities of leadership, demonstrating expertise in the media and instruction fields (Johnson, 1993). 
Noteworthy, complaints about dire physical conditions and disciplinary problems surfaced from respondents themselves, though they were not included in the questionnaire to begin with. Typical remarks were: "I'm a peace keeper", "The library becomes a social gathering spot" (very common comment), "Vandalism, disrespect, theft and contempt", "Students don't consider me authoritative", "There are frequent conflicts", "The library serves as a regular classroom", "The space is too small", "Our location within the school is unsuitable" "The library is in an underground shelter", "It's not air-conditioned", "The inner staircase is very bothersome", etc. The fact that such complaints surfaced in an entirely spontaneous manner attests to their prevalence. Unlike physical conditions that similarly concern all three groups, the disciplinary aspect is particularly disturbing to librarians (over 20\%) but much less to teachers and principals (merely 10-12\%). Since this aspect surfaced in virtually all the personal interviews, it is presumably even more severe in reality although many librarians avoided mentioning it, either because they were uncomfortable admitting it or simply due to oversight since the question referred to major difficulties.

The category of "difficulties related to the library staff's work and personality" included responses indicating problems related to the librarian's personality and hindering the work of the school media center. It includes diverse comments, from all three sectors, for example: "the librarian is too formal", "she cares more about things than about people", "she holds outdated notions of her job", "she's occupied with maintaining order and quiet which doesn't leave much time or energy for innovations", "I don't let them enter the library improperly dressed... if they disobey, I suspend them", "I'm tough and strict", "initiative is not my thing", "there is great discrepancy between what the librarian claims to do and her reluctance to invest" (a principal). Open-ended responses revealed complaints on overly conservative and inflexible character, sometimes unaware of the service aspect of the job.

This finding corroborates the above-mentioned former findings of Christensen (1991), Latrobe (1992), Johnson (1993), and McCracken (2000), regarding the importance of librarian's personality traits such as ambition, leadership and decisiveness, initiative, responsibility, enthusiasm, creativity, willingness to work hard and knowledge of informal education.

\section{Inadequate professional training:}

Regarding "Inadequate professional training", respondents were given a chance to clarify themselves and some did so. A detailed analysis of these responses appears in table 2 . 
Table 2

Problems with the professional training of the librarians

(In descending order of frequency according to librarians' response)

\begin{tabular}{|l|c|c|c|c|c|c|}
\hline & According to & \multicolumn{2}{l|}{ Librarians } & \multicolumn{2}{l|}{ Teachers } & Principals \\
\hline Problems specified & $\%$ & Rank & $\%$ & Rank & $\%$ & Rank \\
\hline $\begin{array}{l}\text { Inadequate skills in } \\
\text { information } \\
\text { technologies }\end{array}$ & 53.1 & $\mathbf{1}$ & 25.0 & $\mathbf{2}$ & 40.5 & $\mathbf{1}$ \\
\hline $\begin{array}{l}\text { Library director } \\
\text { lacks professional } \\
\text { education }\end{array}$ & 25.0 & $\mathbf{2}$ & 16.7 & $\mathbf{3}$ & 32.4 & $\mathbf{2 . 5}$ \\
\hline $\begin{array}{l}\text { Lack of skills of } \\
\text { management, PR } \\
\text { and communication }\end{array}$ & 15.6 & $\mathbf{3}$ & 29.2 & $\mathbf{1}$ & 16.2 & $\mathbf{4}$ \\
\hline $\begin{array}{l}\text { Lack of pedagogical } \\
\text { training and } \\
\text { unfamiliarity with } \\
\text { curriculum } \\
\text { development }\end{array}$ & 12.5 & $\mathbf{4}$ & 12.5 & $\mathbf{4}$ & 32.4 & $\mathbf{2 . 5}$ \\
\hline $\begin{array}{l}\text { Lack of artistic } \\
\text { creativity and of } \\
\text { skills in library } \\
\text { design }\end{array}$ & 9.4 & $\mathbf{5}$ & 4.2 & $\mathbf{6}$ & 5.4 & $\mathbf{5}$ \\
\hline $\begin{array}{l}\text { Lack of wide } \\
\text { general knowledge }\end{array}$ & 6.3 & $\mathbf{6}$ & 8.3 & $\mathbf{5}$ & 2.7 & $\mathbf{6 . 5}$ \\
\hline $\begin{array}{l}\text { Inadequate fluency } \\
\text { in Hebrew language }\end{array}$ & 0 & $\mathbf{7}$ & 0 & $\mathbf{7}$ & 2.7 & $\mathbf{6 . 5}$ \\
\hline \hline \multicolumn{1}{|c|}{$\mathrm{N}$} & $\mathbf{3 2}$ & & $\mathbf{2 4}$ & & $\mathbf{3 7}$ & \\
\hline
\end{tabular}

Note: Percentages total more than $100 \%$ because respondents were allowed to mark more than one option.

Topping the list is the problem of inadequate knowledge and training in information technologies, i.e. computer applications, Internet and computerized databases. More than half the librarians who complained of inadequate professional training noted that they were referring to information technologies, as did $40 \%$ of the principals but only $25 \%$ of the teachers. The second prominent shortcoming (related to "inadequate professional training") was that the library director was not a professionally qualified librarian. According to demographic data, 20\% of librarians lacked specific training. Only one-fourth of the librarians who mentioned the aspect of inadequate training considered it an obstacle and even fewer of the teachers, but a considerable proportion of the principals (32\%) did, reflecting the belief that a library director's lack of professional training compromises his ability to perform his job, as claimed earlier by Christensen (1991) and Shantz (1994).

Admittedly, some professionals assert that common sense, broad knowledge and devotion are more important for a library director than in-depth professional specialization. An assistant proficient in classification and cataloging can free the 
library director for other tasks. General knowledge and the drive to achieve are undoubtedly very important to a librarian's success, but professional training should not be waived. Without a solid background in the information and library sciences, it is impossible to form a library, arrange it methodically and uniformly so it is accessible to the layman, analyze the public's needs and accustom children to be lifelong learners. This fierce debate exists also and perhaps mainly, with employers, as attested by Langerman over a decade ago: "Many employers of librarians and information specialists are convinced that in this field training can be acquired on the job. Specific library and information training is considered a waste of time since any intelligent individual can supposedly learn these things by himself" (Langerman, 1992).

The fact that many librarians lack training in instruction and are unfamiliar with the curriculum or its development deeply concerns principals (32\%) but much less teachers and librarians themselves (12.5\%). The principals' concern is consistent with the situation in the United States, where librarians in an educational institution must be qualified in education or instruction.

It is noteworthy that to those teachers who indicated inadequate professional training as an obstacle, the most important aspects (29\%) were management skills, interpersonal communication and publicity, followed by inadequate knowledge of information technologies (25\%). This may be related to the lack of communication between librarians and teachers and disagreement over the role perception prevailing in some schools. The great importance of cooperation between librarian and teachers was already discussed in detail above (Haycock, 1985; Griffin \& Lamb, 1987; Streatfield \& Markless, 1994; Turner, 1996; Hayden, 2000; Kolencik, 2001) and successful cooperation cannot take place if the librarian lacks the essential skills of interpersonal communication and public relations (Edwards, 1989; Latrobe, 1992; Hartzell, 1997, 2002).

\section{Conclusions and Recommendations}

Obstacles: The three groups of respondents rated quite similarly the obstacles that, in their opinion, hinder the librarian in optimally performing his job. First and foremost was the scarcity of resources and of manpower. Ranked third was inadequate professional training, which was found to include several elements: inadequate training in information technology and in librarianship, inadequate skills of management, public relations and communication as well as lack of training in instruction and lack of familiarity with curriculum and its development. Rated fourth was the principal's and teaching staff's lack of awareness and recognition of library importance, acknowledged also by principals and teachers. Additional obstacles mentioned were poor physical conditions, discipline problems and the character of the librarian and library staff.

The findings of this study corroborate former studies reviewed above and lead to several recommendations, which when implemented may broaden the librarian's impact and his contribution to the school curriculum, since ultimately, the library's goals are also those of the school:

Promoting awareness and understanding of library and librarian roles:

Regrettably, many schools retain outdated and misleading stereotypes regarding the role and position of the school librarians, whose unique position in the school enables them to contribute substantially to student achievement. Findings of the entire study (part of 
which are presented in this paper) suggest that Israeli high school principals, teachers and to some extent, even librarians still do not realize that cooperation between the librarian and teacher is crucial for the success of a school library. In many schools the librarian's roles as advisor on education and instruction and teacher are not yet utilized.

Experts have repeatedly stressed that principals, as school's primary decision makers, as well as teachers, must recognize and comprehend the roles of the school librarian. Our study found among librarians a strong feeling of lack of awareness and recognition of the importance of the library and librarian by principals and teachers, indicating ignorance of the formers' roles. Seemingly, in Israel too, like claimed in professional literature, principal and teacher training programs tend to overlook the vast potential of the school library, librarians' contribution to the curriculum and the need for increased cooperation between them and teachers.

The need for a written document-an Israeli Information Power: Thus, it is recommended that a professional organization formulate a series of documents and programs that unequivocally clarify the role of the school librarian to principals, teachers and to some extent, to librarians themselves. Such publications that will be disseminated by the Ministry of Education in all schools shall explain and demonstrate the potential of library support of school educational goals and include guidelines, options and practical suggestions for reinforcing cooperation between librarians and school staff. It is possible to translate into Hebrew the second edition of Information Power and introduce it into institutions training principals, teachers and librarians. But, it is a lengthy detailed book, containing only guidelines, designed for American school libraries, and written for and by librarians, using their specific terminology, thus probably unsuitable for principals, teachers and even librarians in the different Israeli setting.

Hence, it is preferable to compose a corresponding Israeli manual suited to the local scene, broader and much more detailed than the Ministry of Education General Director circular (1989 and 1996) but less in-depth and specific than Information Power. This manual must also include quantitative standards indicated in this paper as major obstacles (budget, personnel, equipment, etc.) since librarians and principals also need minimal quantitative guidelines to justify their budgetary demands and future planning. Both parts of this manual, the theoretical and quantitative, should be accessible to principals and to directors of librarian training programs.

Courses to principals and teachers on school library's roles: Additionally, university and college experts who compose principal and teacher training programs should be contacted and persuaded to incorporate into the curriculum at least one course on the school library's roles, emphasizing the rationale behind Information Power or its prospective Israeli counterpart. Schools and education and librarianship/information science departments should cooperate both by devising learning units to be taught in principal training courses and by arranging joint courses dealing with the school library, its benefits and roles, for future librarians and principals, thus accustoming them to collaboration even before they begin practicing their profession. A similar course should be incorporated in teacher training programs, in conjunction with librarians or separately, focusing on the issue of teacher expectations from the librarian and library. Introducing this issue in teachers' courses is of the utmost importance, both in the very cooperation between teacher and librarian and since most principals are initially teachers and will eventually reach this position with positive library experiences. 
Cooperation between professional organizations regarding continuing education: The ultimate goal should be for all school parties to have a common vision regarding the library. To this end, professional organizations of school librarians must collaborate with organizations of teachers and principals, in organizing joint continuing education programs, including the publishing of a principal's guide explaining library and librarians' roles in school. Librarians and library educators could also contribute by publishing articles advocating this cause in teachers and principals journals.

Adding personnel positions in school libraries: Findings clearly indicate the acute problem of lack of time: librarians feel flooded and overwhelmed by too heavy work load, a direct result of the widening role definition and the steep rise of topics and responsibilities required in limited time. Thus, it is essential that librarians' organizations, academia professors and Ministry of Education will cooperate in demanding an increase of manpower in school libraries.

Emphasizing technological topics in library education programs: The prevalent complaint regarding lack of skills in information technology calls for continuing and strengthening the current trend of emphasizing the technological topics in library education programs, including advanced courses in information storage and retrieval. No doubt that a friendly and service-oriented librarian may encourage users to come to the library, but usually people come mainly to seek information, advice and guidance and only fulfillment of these needs will encourage them to come again. Therefore, the school librarian should posses the skill to guide students and teachers alike, how to find needed information using traditional and modern techniques. School librarians must be highly aware of changes in the profession if they want to retain and even to upgrade and elevate their stand and status at school. 


\section{References}

American Association of School Librarians and Association for Educational Communications and Technology (1988). Information Power: Guidelines for School Library Media Programs. Chicago, Il.: American Library Association and Association for Educational communications and Technology.

American Association of School Librarians and Association for Educational Communications and Technology (1998). Information Power: Building Partnerships for Learning. Chicago: American Library Association.

Bishop, Faira Lee. (1989). The role of the school library media specialist as perceived by selected Mississippi principals, classroom teachers, school library media specialists and library media educators. Doctoral dissertation, University of Southern_Mississippi.

Burnell, Sally. (1978). Principals' perceptions of actual and ideal roles of the school library media specialist. Iowa: Ames Community Schools.

Callison, D. \& Morris, J. (1986). Case Studies in Managing School Library Media centers. Phoenix, Orix Press.

Christensen, P.M. (1991). Characteristics of library media specialists who have exemplary high-school library media programs. School Library Media Quarterly, 19, 247-252.

Edwards, K.K. (1989). Principals' perceptions of librarians. School Library Journal, 35(5), 28-31.

Ervin, D.S. (1989). The Effect of Experience, Educational Level, and Subject Area on the Philosophical Acceptance, the Perceived Assumption and the Perceived Barriers to Implementation of the Instructional and Curricular Role of the School Library Media Specialist. Doctoral dissertation, University of South Carolina.

Gehlken, Vivian Seiber. (1994). The role of the high-school library media programs in the nationally recognized South Carolina Blue Ribbon secondary schools. Doctoral dissertation, University of South Carolina.

Getz, Irith (1996). Attitudes of preservice and inservice teachers toward working with school librarians. School Libraries Worldwide, 2(1), 59-70.

Glick, A. (2001). School Libraries top agenda. School Library Journal, 47(4), 19.

Griffin D. \& Lamb, J.A. (1987). Positive Relationships produce positive results. School Library Journal, 34(3), 27-29.

Hartzell, Gary N. (1997). The Invisible school librarian: Why other educators are blind to your value. School Library Journal, 43(11), 24-29.

Hartzell, Gary. (2002). The principals' perceptions of school libraries and teacherlibrarians. School Libraries Worldwide, 8(1), 92-110.

Haycock, Ken. (1985a). Services of school resource centers. Emergency Librarian 213 , 28-29.

Haycock, Ken. (1985b). Strengthening the foundations for teacher- librarians. School Library Media Quarterly, 13(2), 102-109.

Haycock, Ken. (1999). Partnerships and leadership: TLs in new roles. Teacher Librarian, 26(3), 7.

Hayden, Janis. (2000). Perceptions, beliefs and expectations of preservice and experienced middle school teachers regarding the roles of school library media specialists. Doctoral dissertation, Georgia State University. 
Heeks, Peggy \& Kinnell, Margaret. (1994). School libraries at work. London: British Library Research and Development Department. (Serial, no. 96).

Hopkins, D.M. \& Zweizig, D.L. (1 ${ }^{\text {st }}$ of May,1999). Power to the media center (and to the people, too). School Library JournalOnline:Articles.<http://www.bookwire.com/slj/articles\$28417>

Johnson, Julia A. (1993). The school library media specialist as instructional consultant. Doctoral dissertation, Southern Illinois University at Carbondale.

Kennedy-Manzo Kathleen (22 of March, 2000). Study shows rise in test scores tied to school library resources. Education Week on the web.<http://www.edweek.org/ew/ewstory.c >

Kolencik, Patricia Liotta. (2001). Principals and teacher librarians: Building collaborative partnerships in the learning community. Doctoral. dissertation, University of Pittsburgh.

Langerman, S. (1992). "The librarian in the last decade of the $20^{\text {th }}$ century", Alon Asmi, 19(1), 5-7. (in Hebrew)

Latrobe, K.H. (1992). Evaluating library media programs in terms of Information Power: Implications for theory and practice. School Library Media Quarterly, 21(1), 37-43.

Lifer, E. (2002). Five biggest challenges for 2002. School Library Journal, 48(1), 5053.

Master, N.L. \& Master, L.S. (1986). Perceptions of School Librarians as Curriculum Leaders. Las Vegas, University of Nevada.

McCarthy, Cheryl A. (1997). A reality check; the challenges of implementing Information Power in school library media Programs. School Library Media Quarterly, 25(4), 205-214.

McCracken, Anne (2000). Perceptions of school library media specialists regarding their roles and practices. Doctoral dissertation, Virginia: George Mason University.

Macintosh, C. (1994). The Evolution of the Role of the K-122 Public School Media Specialist. Doctoral dissertation, Kentucky Spalding University.

Oberg, Dianne. (1996). Principal support: What does it mean to teacher-librarians? in L.A. Clyde (Ed.) Sustaining the Vision; a collection of article and papers on research in school librarianship. (pp. 221-229) Colorado: Hi Wilson Research and publication.

Roach, C.P. (1989). Attitudes toward the Contemporary Role of the School Library Media Specialist in the Overall Elementary School Program. Doctoral dissertation, University of North Texas.

Sadowski, M. \& Meyer, R. (1994). Staffing for success. School Library Journal, 40(6), 29-31.

Shantz, Doreen. (1994). What is the purpose of program advocacy? Why should teacher-librarians be involved with program advocacy? Emergency Librarian , 21(3), 22-25.

Streatfield, David \& Markless, Sharon. (1994). Invisible Learning? The contribution of school libraries to teaching and learning. Cambridge: The British Library Board. (Report 98).

Stripling, Barbara. (1997). Library Power: A model for school change. School Library Media Quarterly, 25(4), 2-6. 
Turner, Philip M. (1985). A School Library Media Specialist's Role; Helping Teachers Teach. Littleton, Co. Libraries Unlimited.

Turner, Philip M. (1996). What help do teachers want, and what will they do to get it? School Library Media Quarterly, 24(4), 208-212.

Turner, P.M. \& Zsiray, S.W. (1990). The consulting role of the school library media specialist. . in B. Wools (Ed.), The Research of School Library Media Centers (pp. 1-20). Castle Rock, Co.: Hi Willow Research \& pub.

Vansickle, S. (2000). Educating preservice media specialists: Developing school leaders. School Libraries Worldwide, 6(2), 1-20.

Wilson, Patricia \& McNeil, Angus (1998). In the dark: what's keeping principals from understanding libraries? SchoolLibraryJournalOnline $\quad .1 \quad$ Sep.1998 $<$ http://www.bookwire.com/slj/articles.article\$25872>

\section{Authors Note}

Moshe Yitzhaki: Born 1940 in Tiberias, Israel. Received the BA degree in economics and biblical studies and the MA degree in biblical studies from Bar-Ilan University, Ramat-Gan, Israel, Received the Master in Library Science (MLS) degree from Rutgers-The State University of New-Jersey, USA, followed by the PhD degree there, after writing a dissertation, guided by professor Henry Voos, on "Citation patterns in the fields of biblical and ancient Near-East studies". Teaches full-time at the Department of Information Studies at Bar-Ilan University from 1980 on. Main Areas of research and publication (over 50 articles): school library, children's literature, bibliometrics and informetrics, (especially title informativity and language barrier), information seeking and flow.

Dania Anzenberg: Received the MA degree in library studies from the School of Librarianship, The Hebrew University, Jerusalem. Later studied in the PhD program in the Department of Information Studies at Bar-Ilan University, where she recently completed her dissertation, guided by Dr. Moshe Yitzhaki, on the various perceptions of the school librarian's roles. Worked for many years as a high school librarian in Jerusalem, enjoying principal's and teachers' cooperation, and was recently chosen to head the David Yellin Teachers' College library at Jerusalem as well as its newlyestablished track of Librarianship Studies. Main Areas of interest are school librarianship, especially reading encouragement, on which she wrote a book designed for practitioners. 
Reproduced with permission of the copyright owner. Further reproduction prohibited without permission. 